eISSN: $2655-8688$

http://jurnal.stikes-sitihajar.ac.id/index.php/jhsp hal:61-67

Copyright @2020. This is an open-access arcle distributed under the terms of the Creavec permits unrestricted non-commercial used, distribuon and reproducon in any medium
pISSN: 2548-3943

Received Juli, Accepted Sept, Publish Januari Volume 2, Nomor 1 - 2020

\title{
Determinan yang Berhubungan dengan Keluhan Akibat Tidak Menggunakan APD pada Pekerja Bengkel Las Medan
}

\section{Yuna Asima Ria Lumban Gaol ${ }^{1 *}$, Perry Boy Chandra Siahaan ${ }^{1}$}

${ }^{1}$ Ilmu Kesehatan Masyarakat, Fakultas Kesehatan Masyarakat, Universitas Prima Indonesia Email: yuna.lumbangaol@yahoo.com

\begin{abstract}
ABSTRAK
Penggunaan Alat Pelindung Diri (APD) sangat penting dalam pekerjaan seharihari baik pekerjaan formal dan informal, maka itu manfaat menggunakan Alat Pelindung Diri (APD) saat bekerja sangat besar dalam pencengahan kecelakaan dan penyakit akibat kerja tetapi tidak menjamin semua pekerjaan akan memakainya. Tujuan umum penelitian ini adalah untuk Mengetahui Faktor- Faktor Yang Berhubungan Dengan Keluhan Akibat Tidak Menggunakan Alat Pelindung Diri (APD) Pada Pekerja Las di Bengkel Las yang berlokasi di Jalan Mahkamah Kelurahan Mesjid pada tahun 2019. Adapun penelitian ini adalah survei analitik dengan menggunakan Cross Sectional dengan sampel 30 orang. Penelitian ini menggunakan metode analisa data chi-square untuk mengetahui hubungan yang signifikan antara, APD, Cara Kerja, Lama Kerja dengan Keluhan Pada Pekerja Las. Penelitian ini menunjukkan adanya hubungan APD dengan Keluhan Pada Pekerja Las, kemudian adanya hubungan Cara Kerja dengan Keluhan Pada Pekerja Las, dan tidak adanya hubungan Lama Kerja dengan Keluhan Pada Pekerja Las.
\end{abstract}

Kata kunci: Alat Pelindung Diri, keluhan, cara kerja, lama kerja

\section{ABSTRACT}

The use of Personal Protective Equipment (PPE) is very important in the daily work of both formal and informal work, so the benefits of using Personal Protective Equipment (PPE) when working very much in the midst of accidents and occupational diseases but do not guarantee that all jobs will be used. The objective of this study is to identify any Factors Associated with Complaints Due to Not Using Personal Protective Equipment (PPE) on Welding Workers in Welding Workshop on Jalan Masjid Kelurahan Court in 2019. This study is an analytical survey by using Cross Sectional technique with a sample of 30 people. This study uses the chi-square data analysis method to determine the significant relationship between, PPE, How to Work, Length of Work with Complaints on Welding Workers. The results of this study showed that there was a relationship between PPE and Complaints on Welding Workers, a relationship between How to Work with Complaints on Welding Workers, and no relationship between Length of Work with Complaints on Welding Workers.

Keywords : Personal Protective Equipment, complaints, how to work, length of work 


\section{Pendahuluan}

Penggunaan Alat Pelindung Diri (APD) merupakan tahapan pengendalian kecelakaan kerja paling akhir dari metode pengendalian bahaya kecelakaan dan penyakit akibat kerja. Penggunaan APD sangat penting dalam pekerjaan sehari- hari baik pekerjaan formal dan informal, maka itu manfaat menggunakan APD saat bekerja sangat besar dalam pencengahan kecelakaan dan penyakit akibat kerja tetapi tidak menjamin semua pekerjaan akan memakainya. namun dalam kenyataanya banyak yang tidak menggunakan APD karena kurangnya kesadaran para pekerja untuk senantiasa menggunakan APD.

Telah menjadi budaya kerja, dalam pemakaian APD, masih banyak yang enggan menggunakan APD dengan alasan menyulitkan bagi mereka saat bekerja serta merasa ketidaknyamanan dan mengurangi produktifitas. Peralatan APD sering tidak digunakan para pekerja karena tidak hanya sedikit para pekerja yang sadar akan pentingnya menggunakan APD, namun juga ditemui para pengguna APD tidak memenuhi standar atau terkesan asal pakai.

Pembangunan sektor informal telah banyak memberikan dampak positif terhadap perekonomian Indonesia serta banyak tercipta lapangan kerja yang cukup besar, meningkatkan pendapatan dan kesejahteraan masyarakat. Salah satu industri informal yang banyak di medan adalah industri pengelasan atau bengkel las, di Jalan Mahkamah Medan Lingkungan 7 Kelurahan Mesjid Kecamatan Medan Kota Provinsi Sumatera Utara terdapat 25 bengkel industri las rumahan yang jumlah pekerja di tiap bengkelnya kurang lebih dari enam. Tukang las seringkali berpotensi terkena bahaya ditempat kerja yang berpotensi menimbulkan bahaya bagi kesehatan mereka terutama ketika paparan yang terjadi cenderung secara teratur. Salah satu faktor resiko bahaya yang ada Pada lingkungan kerja asap las, gas nitrogen oksida,gas nitrogen dioksida, Segatan listrik, percikan Las, bahaya ledakan dan bahaya kebakaran serta dampak resiko terhadap pekerja las yaitu cahaya ultraviolet, sinar inframerah, yang dihasilkan dari proses pengelasan.

Berdasarkan hasil penelitian terdahulu, terdapat keluhan pada pekerja las yang bekerja selama 6-12 jam dimana dapat menimbulkan rasa ada benda asing, banyak mengeluarkan air mata, rasa silau, terasa bakar atau panas pada mata, terasa perih, kelopak mata terasa bengkak dan gangguan penglihatan menjadi kabur atau tidak jelas, oleh karena itu keluhan ini dapat mengakibatkan turunnya produktivitas pekerja las. Kemudian berdasarkan penelitian terdahulu, para pekerja yang tidak disiplin dalam pemakaian APD dapat menyebabkan mata mengalami trauma fisik yang berupa sinar infra merah yang dihasilkan oleh pancaran sinar las listrik.

Berdasarkan latar belakang tersebut, maka penelitian ini bertujuan untuk mengetahui "Determinan yang Berhubungan Dengan Keluhan Akibat Tidak Menggunakan Alat Pelindung Diri (APD) pada Pekerja Bengkel Las di Jalan Mahkamah Mesjid Raya Medan”.

\section{Metode}

Penelitian ini merupakan jenis penelitian analitik, dengan menggunakan desain CrossSectional yaitu mencari hubungan variabel independen dengan variabel dependen. Penelitian ini dilaksanakan pada salah satu Bengkel Las yang berlokasi di Jalan Mahkamah Kelurahan Mesjid, Kecamatan Medan Kota, Provinsi Sumatera Utara Tahun 2019. Waktu Penelitian ini dilaksanakan dari bulan September 2018 sampai dengan selesai. Populasi dalam penelitian ini merupakan seluruh pekerja yang ada di 25 bengkel las di kawasan jalan Mahkamah Kelurahan Mesjid Kecamatan Medan Kota yang berjumlah 58 pekerja laki-laki, sedangkan sampel berjumlah 30 orang pekerja yang dipilih berdasarkan teknik Purposive Sampling.

Variabel yang digunakan dalam penelitian ini adalah Alat Pelindung Diri, Cara Kerja, dan Lama Bekerja sebagai variabel independen, kemudian Keluhan Pada Pekerja Bengkel Las sebagai variabel dependen. Data yang digunakan dalam penelitian ini merupakan data primer yang diperoleh dengan menggunakan kuesioner. Data dianalisa dengan menggunakan chi- 
square, dan diolah dengan menggunakan bantuan software Statistical Package for the Social Sciences (SPSS) versi 24.

\section{Hasil}

Bengkel Las jalan Mahkamah Medan terletak di lingkungan 7 kelurahan Masjid, Kecamatan Medan Kota, Kota Medan, Provinsi Sumatra Utara. Bengkel Las terdiri dari 25 bengkel dan memiliki pekerja yang berbeda-beda. Salah satu bengkel las yang terdiri dari 1-4 pekerja tetap semuanya adalah laki-laki. Bengkel las dikelola secara perorangan yang menghasilkan berbagai produk.

Berdasarkan hasil penelitian, data yang dikumpulkan dimasukkan kedalam bentuk penyajian tabel yang berfungsi untuk memudahkan atau menyederhanakan setiap variabel yang akan diteliti. Adapun hasil pengumpulan data dikumpulkan melalui kuesioner yang dibagikan kepada responden. Jumlah responden dari perhitungan sampel yang telah dilakukan adalah sebanyak 30 orang. Karakteristik responden dalam penelitian ini meliputi umur, jenis kelamin, dan pendidikan, dapat dilihat dalam tabel berikut:

\section{Tabel 1. Karakteristik Responden}

\begin{tabular}{|c|c|c|}
\hline Karakteristik & n & $\%$ \\
\hline \multicolumn{3}{|l|}{ Umur } \\
\hline $25-30$ & 8 & 27 \\
\hline $31-35$ & 10 & 33 \\
\hline $36-40$ & 11 & 37 \\
\hline $41-45$ & 1 & 3 \\
\hline \multicolumn{3}{|l|}{ Jenis Kelamin } \\
\hline Laki-laki & 30 & 100 \\
\hline Perempuan & 0 & 0 \\
\hline \multicolumn{3}{|l|}{ Pendidikan } \\
\hline SD & 16 & 53 \\
\hline SMP & 3 & 10 \\
\hline SMA / STM & 11 & 37 \\
\hline Total & 30 & 100 \\
\hline
\end{tabular}

Berdasarkan distribusi frekuensi kelompok umur, mayoritas responden kelompok umur 36-40 tahun sebanyak 11 orang (37\%) dan minoritas kelompok umur 41->45 tahun sebanyak 1 orang $(3 \%)$. Berdasarkan distribusi frekuensi jenis kelamin, bahwa semua berjenis kelamin lakilaki sebanyak 30 orang $(100 \%)$. Berdasarkan distribusi frekuensi pendidikan, mayoritas pendidikan responden adalah SD sebanyak 16 orang (53\%) dan minoritas pendidikan responden adalah SMP sebanyak 3 orang (10\%).

Kemudian berikut ini adalah karakteristik responden mengenai Alat Pelindung Diri, Cara Kerja, Lama Kerja yang mempengaruhi Keluhan Pada Pekerja yang dapat dilihat dalam tabel sebagai berikut: 
Tabel 2. Distribusi Frekuensi berbagai Faktor yang Mempengaruhi Keluhan Pekerja Las

\begin{tabular}{|c|c|c|}
\hline Kriteria & $\mathbf{n}$ & $\%$ \\
\hline \multicolumn{3}{|l|}{ APD } \\
\hline Lengkap & 5 & $17 \%$ \\
\hline Tidak lengkap & 25 & $83 \%$ \\
\hline \multicolumn{3}{|l|}{ Cara Kerja } \\
\hline Aman & 10 & $33 \%$ \\
\hline Tidak Aman & 20 & $67 \%$ \\
\hline \multicolumn{3}{|l|}{ Lama Kerja } \\
\hline$\leq 8$ jam & 13 & $43 \%$ \\
\hline$>8$ jam & 17 & $57 \%$ \\
\hline \multicolumn{3}{|l|}{ Keluhan Pekerja } \\
\hline $\mathrm{Ya}$ & 19 & $63 \%$ \\
\hline Tidak & 11 & $37 \%$ \\
\hline Total & 30 & $100 \%$ \\
\hline
\end{tabular}

Berdasarkan data pada tabel diatas, bahwa dari 30 responden mayoritas responden menggunakan APD tidak lengkap yaitu sebanyak 25 orang (83\%). Minoritas responden menggunakan APD lengkap yaitu sebanyak 5 orang (17\%). Berdasarkan data pada tabel diatas, bahwa dari 30 responden mayoritasi responden merasa cara kerja tidak aman yaitu sebanyak 20 orang (67\%). Minoritas responden merasa cara kerja aman yaitu sebanyak 10 orang (33\%). Berdasarkan data pada tabel diatas, bahwa dari 30 responden mayoritas responden bekerja selama $>8$ jam yaitu sebanyak 17 orang (57\%). Minoritas responden bekerja selama $\leq 8$ jam yaitu sebanyak 13 orang (43\%). Berdasarkan data pada tabel diatas, bahwa dari 30 responden mayoritas responden mengalami keluhan yaitu sebanyak 19 orang $(63 \%)$. Minoritas responden tidak mengalami keluhan yaitu sebanyak 11 orang (37\%).

\section{Hubungan Alat Pelindung Diri dengan Keluhan Pekerja Las}

Dari 30 responden, sebanyak 5 responden menggunaan APD secara lengkap dan tidak mengalami keluhan (100\%). Sedangkan 25 responden memilih untuk tidak menggunakan APD secara lengkap mayoritas memiliki keluhan sebanyak 18 orang (72\%) dan minoritas tidak memiliki keluhan sebanyak 7 orang (28\%). Lengkapnya bisa dilihat pada tabel berikut:

Tabel 3. Hubungan APD dengan Keluhan Pada Pekerja Las

\begin{tabular}{|c|c|c|c|c|c|c|c|}
\hline \multirow{3}{*}{ Penggunaan APD Secara } & \multicolumn{4}{|c|}{ Keluhan Pada Pekerja Las } & \multirow{2}{*}{\multicolumn{2}{|c|}{ Total }} & \multirow{3}{*}{$\mathbf{p}$} \\
\hline & \multicolumn{2}{|c|}{ Ya } & \multicolumn{2}{|c|}{ Tidak } & & & \\
\hline & $\mathbf{n}$ & $\%$ & $\mathbf{n}$ & $\%$ & $\mathbf{N}$ & $\%$ & \\
\hline Lengkap & 0 & $0 \%$ & 5 & $100 \%$ & 5 & $17 \%$ & 0,006 \\
\hline Tidak Lengkap & 18 & $72 \%$ & 7 & $28 \%$ & 25 & $83 \%$ & \\
\hline Total & 18 & $100 \%$ & 12 & $100 \%$ & 30 & $100 \%$ & \\
\hline
\end{tabular}

Berdasarkan hasil statistik dapat diketahui bahwa nilai p-value lebih kecil daripada nilai alfa $(0,006<0,05)$, artinya $\mathrm{H}_{0}$ diterima, yang menunjukkan bahwa terdapat hubungan yang signifikan antara Alat Pelindung Diri dengan Keluhan Pada Pekerja Las Di Bengkel Las Di 
Jalan Mahkamah Kelurahan Mesjid Kecamatan Medan Kota Provinsi Sumatera Utara Tahun 2019.

\section{Hubungan Cara Kerja dengan Keluhan Pekerja Las}

Dari 10 responden yang merasa cara kerja aman mayoritas tidak memiliki keluhan sebanyak 7 orang $(70 \%)$ dan minoritas memiliki keluhan sebanyak 3 orang (30\%). Dari 20 responden yang merasa cara kerja tidak aman mayoritas memiliki keluhan sebanyak 15 orang (75\%) dan minoritas tidak memiliki keluhan sebanyak 5 orang (25\%). Lengkapnya bisa dilihat pada tabel berikut:

Tabel 4. Hubungan Cara Kerja dengan Keluhan Pada Pekerja Las

\begin{tabular}{|c|c|c|c|c|c|c|c|}
\hline \multirow{3}{*}{ Cara Kerja } & \multicolumn{4}{|c|}{ Keluhan Pada Pekerja Las } & \multirow{2}{*}{\multicolumn{2}{|c|}{ Total }} & \multirow{3}{*}{$\mathbf{p}$} \\
\hline & \multicolumn{2}{|c|}{ Ya } & \multicolumn{2}{|c|}{ Tidak } & & & \\
\hline & $\mathbf{n}$ & $\%$ & $\mathbf{n}$ & $\%$ & $\mathbf{N}$ & $\%$ & \\
\hline Aman & 3 & $30 \%$ & 7 & $70 \%$ & 10 & $33 \%$ & 0,025 \\
\hline Tidak aman & 15 & $75 \%$ & 5 & $25 \%$ & 20 & $67 \%$ & \\
\hline Total & 18 & $100 \%$ & 12 & $100 \%$ & 30 & $100 \%$ & \\
\hline
\end{tabular}

Berdasarkan hasil statistik dapat diketahui bahwa nilai p-value lebih kecil daripada nilai alfa $(0,025<0,05)$, artinya $\mathrm{H}_{0}$ diterima, yang menunjukkan bahwa terdapat hubungan yang signifikan antara cara kerja dengan Keluhan Pada Pekerja Las Di Bengkel Las Di Jalan Mahkamah Kelurahan Mesjid Kecamatan Medan Kota Provinsi Sumatera Utara Tahun 2019.

\section{Hubungan Lama Kerja dengan Keluhan Pekerja Las}

Dari 13 responden yang bekerja selama $\leq 8$ jam mayoritas memiliki keluhan sebanyak 7 orang $(53,8 \%)$ dan minoritas tidak memiliki keluhan sebanyak 6 orang (46,2\%). Dari 17 responden yang bekerja selama $>8$ jam mayoritas memiliki keluhan sebanyak 11 orang $(64,7 \%)$ dan minoritas tidak memiliki keluhan sebanyak 6 orang (35,3\%). Lengkapnya bisa dilihat pada tabel berikut:

Tabel 5. Hubungan Lama Kerja dengan Keluhan Pada Pekerja Las

\begin{tabular}{|c|c|c|c|c|c|c|c|}
\hline \multirow{3}{*}{ Lama Kerja } & \multicolumn{4}{|c|}{ Keluhan Pada Pekerja Las } & \multirow{2}{*}{\multicolumn{2}{|c|}{ Total }} & \multirow{3}{*}{$\mathbf{p}$} \\
\hline & \multicolumn{2}{|c|}{ Ya } & \multicolumn{2}{|c|}{ Tidak } & & & \\
\hline & $\mathbf{n}$ & $\%$ & n & $\%$ & $\mathbf{N}$ & $\%$ & \\
\hline$\leq 8 \mathrm{Jam}$ & 7 & $54 \%$ & 6 & $46 \%$ & 13 & $43 \%$ & 0,41 \\
\hline$>8 \mathrm{Jam}$ & 11 & $65 \%$ & 6 & $35 \%$ & 17 & $57 \%$ & \\
\hline Total & 18 & $100 \%$ & 12 & $100 \%$ & 30 & $100 \%$ & \\
\hline
\end{tabular}

Berdasarkan hasil statistik dapat diketahui bahwa nilai p-value lebih besar daripada nilai alfa $(0,410>0,05)$, artinya $\mathrm{H}_{0}$ ditolak, yang menunjukkan bahwa tidak ada hubungan yang signifikan antara lama kerja dengan Keluhan Pada Pekerja Las Di Bengkel Las Di Jalan Mahkamah Kelurahan Mesjid Kecamatan Medan Kota Provinsi Sumatera Utara Tahun 2019.

\section{Pembahasan}

\section{Hubungan Alat Pelindung Diri dengan Keluhan Pekerja Las}

Hasil penelitian menunjukkan bahwa pekerja memiliki sikap yang mengabaikan pemakaian APD dengan lengkap atau tidak teratur, sebagian besar pekerja mengetahui bahaya dari pengelasan apabila tidak menggunakan APD dan sebagian besar pekerja juga kurang mengetahui manfaat dari penggunaan APD seperti pemakaaian tameng dan kacamata, mereka 
beranggapan bahwa tameng dapat diganti dengan kacamata gelap biasa. Kebiasaan lingkungan kerja sekitar mempunyai tingkat yang tidak terbiasa memakai APD yang lengkap juga dapat mempengaruhi pekerja lain untuk tidak menggunakan APD saat bekerja. ${ }^{7}$

Pekerja dalam pemakaian Alat Pelindung Diri (APD) masih banyak yang enggan menggunakan Alat Pelindung Diri (APD) dengan alasan menyulitkan bagi mereka saat bekerja serta merasa ketidaknyamanan dan mengurangi produktifitas. Peralatan Alat Pelindung Diri (APD) sering tidak digunakan para pekerja hanya sedikit para pekerja yang sadar akan pentingnya menggunakan Alat Pelindung Diri (APD) namun ditemui para pengguna Alat Pelindung Diri (APD) tidak memenuhi standar atau terkesan asal pakai.

Selain itu kurangnya pengawasan dari pemilik bengkel las terhadap pekerja untuk menggunakan APD lengkap, sehingga akan menyebabkan turunnya kedisiplinan pekerja terhadap kesehatan dan keselamatan dirinya sendiri yang akhirnya dapat menimbulkan keluhan-keluhan kesehatan yang dialamai kemudian harinya. Upaya yang dapat dilakukan ialah pengawasan yang lebih teratur, tujuannya untuk bisa menjamin bahwa setiap pekerja bekerja dengan aman dan sesuai prosedur keselamatan.

\section{Hubungan Cara Kerja dengan Keluhan Pekerja Las}

Hasil penelitian menunjukkan bahwa semakin berpengalaman seseorang dalam melaksanakan tugasnya atau pekerjaannya, maka akan memberikan sikap yang negative terhadap pekerjaan yang dilakukan, yang artinya pekerja merasa pekerjannya terlalu mudah karena sering dilakukan. Ini menyebabkan sebagian pekerja tidak terlalu memperhatikan cara kerja atau prosedur kerja yang baik dengan mengikuti peraturan yang ada seperti penggunaan APD yang lengkap, pengecekkan alat untuk mengetahui keamanannya dan prosedur kerja yang baik dan aman untuk kesehatan dan keselamatan kerja.

Maka dengan begitu pekerja lebih nyaman dengan cara kerja mereka selama ini yang tidak sesuai dengan prosedur. Contohnya cara kerja pekerja yang mengelas tidak memberikan jarak antara wajah dengan titik pengelasan yang dapat menyebabkan penyakit akibat kerja atau akan terjadi kecelakaan kerja yang dapat membahayakan pekerja itu sendiri. ${ }^{8}$

\section{Hubungan Lama Kerja dengan Keluhan Pekerja Las}

Hasil penelitian menunjukkan bahwa tidak ada hubungan antara lama bekerja dengan keluhan pada pekerja bengkel las. pekerja memiliki waktu bekerja yaitu 8 jam perhari dengan waktu istirahat 1-2 jam. Semakin lama pekerja berada dilingkungan kerjanya, maka pekerja akan merasa jenuh dengan situasi dan pekerjaan yang mereka lakukan. Tetapi dalam kenyataannya dari hasil penelitian diketahui bahwa tidak ada hubungan antara lama kerja dengan keluhan pekerja las.

Kurangnya pengawasan saat bekerja, dikarenakan sebagian pemilik bengkel ikut bekerja dalam proses pengelasan yang menyebabkan kurangnya pengawasan terhadap pekerja termasuk waktu bekerja. Akan tetapi waktu bekerja harus tetap diperhatikan untuk kesehatan dan keselamatan selama bekerja. ${ }^{9}$

Peraturan yang diterapkan oleh pemilik usaha kepada para pekerja bersifat lisan sehingga terdapat kemungkinan pekerja melakukan pekerjaan dengan baik. Kalau pekerja melakukan pekerjaan dengan baik, reward yang diberikan tidak signifikan atau berarti karena penghargaan hanya berupa penambahan pendapatan saja. Adapun bengkel las yang memiliki penghargaan terhadap pengunaan APD di tempat kerja,masih ada saja pekerja yang tidak menggunakannya. ${ }^{10}$ 


\section{Kesimpulan}

Ada hubungan yang signifikan antara Alat Pelindung Diri dengan Keluhan Pada Pekerja Las Di Bengkel Las Di Jalan Mahkamah Kelurahan Mesjid Kecamatan Medan Kota Provinsi Sumatera Utara Tahun 2019. Ada hubungan yang signifikan antara Cara Kerja dengan Keluhan Pada Pekerja Las Di Bengkel Las Di Jalan Mahkamah Kelurahan Mesjid Kecamatan Medan Kota Provinsi Sumatera Utara Tahun 2019. Tidak ada hubungan yang signifikan antara Lama Kerja dengan Keluhan Pada Pekerja Las Di Bengkel Las Di Jalan Mahkamah Kelurahan Mesjid Kecamatan Medan Kota Provinsi Sumatera Utara Tahun 2019.

\section{Referensi}

David E.R, Eram T.P, Widya H.C. Hubungan Pemakaian Alat Pelindung Pernapasan deengan Tingkat Kapasitas Vital Paru. Unnes Journal of Public Health. 2012;1(1):12-17.

Putri S.H, Irwandi R, Firdaus S. Faktor-Faktor yang Berhubungan dengan Keluhan Mata pada Pekerja Las Industri Kecil di Kecamatan Tungkal Ilir Kabupaten Tanjab Barat Tahun 2017. Riset Informasi Kesehatan. 2017;6(2):142-151.

Nur N.L. Keluhan Subjektif Photokeratitis pada Mata Pekerja Las Sektor Informal di Kelurahan Cirendeu dan Ciputat Tangerang Selatan. Prosiding Seminar Nasional IKAKESMADA. 2017:199-204.

Raodhah S. Faktor-Faktor Yang Berhubungan Dengan Penggunaan Alat Pelindung Diri Pada Karyawan Bagian Packer PT. Semen Bosowa Maros Tahun 2014. Public Health Science Journal. 2014;6(2):437-449.

Notoatmodjo S. Promosi kesehatan dan perilaku kesehatan. Jakarta: Rineka Cipta; 2012.

Tri W. Faktor Risiko yang Berhubungan Dengan Kejadian Konjungtivitis Pada Pekerja Pengelasan di Kecamatan Cilacap Tengah Kabupaten Cilacap. Jurnal Kesehatan Masyarakat. 2013;2(1):1-9.

Rizky A.F. Faktor yang Berhubungan Dengan Perilaku Penggunaan Alat Pelindung Diri Pekerja Pengelasan Galangan Kapal. Journal of Industrial Hygiene and Occupational Health. 2018;3(1):23-33.

Amris D, Putri H. Faktor-Faktor yang Berhubungan Dengan Perilaku Keselamatan Pada Pekerja Bengkel Las di Wilayah Pejompongan Kelurahan Bendungan Hilir Jakarta Pusat Tahun 2016. Ilmu Kesehatan Universitas Unggul. 2016:1-13.

Rama S. Konsep dan Teknik Pelaksanaan Riset Keperawatan. Medan: PT. Bina Medika Perintis.

Sulaiman S, Anggreini. Efek Postur Tubuh Terhadap Keseimbangan lanjut Usia di Desa Suka Raya Kecamatan Pancur Batu. Jurnal JUMANTIK Vol. 3 No.2 November 2018. http://jurnal.uinsu.ac.id/index.php/kesmas/article/view/2875 